\title{
Interactivity in Cybermedia News: An Interview with Journalists in Colombia, Peru, and Ecuador
}

\author{
Daniel Barredo Ibáñez ${ }^{1, * \mathbb{D}}$, Karen Tatiana Pinto Garzón ${ }^{2} \mathbb{D}$, Úrsula Freundt-Thurne ${ }^{3}$ and \\ Narcisa Medranda Morales ${ }^{4}$ \\ 1 School of Human Sciences, Universidad del Rosario, Bogotá 110821, Colombia \\ 2 School of Social Sciences, Universidad del Rosario, Bogotá 110821, Colombia; karen.pinto@outlook.es \\ 3 School of Communications, Universidad Peruana de Ciencias Aplicadas, Lima 15023, Peru; \\ ursula.freundt@upc.pe \\ 4 School of Communications, Universidad Politécnica Salesiana, Quito 170143, Ecuador; \\ nmedranda@ups.edu.ec \\ * Correspondence: daniel.barredo@urosario.edu.co; Tel.: +0057-312970200 (ext. 3827)
}

Received: 11 April 2019; Accepted: 6 May 2019; Published: 9 May 2019

\begin{abstract}
Interactivity is a factor on which cyber journalism is based and summarizes participation options between a user and the medium, a user with other users, and a user with editors. In this study, we focus on the latter in three countries-Colombia, Peru, and Ecuador-, which have been identified owing to their technological gap and the emerging importance of online communication for their respective societies. Through 35 in-depth interviews with journalists from these countries, we analyzed the concept of interactivity of these professionals and their relationship with users. The results revealed that the journalists positively valued civic contributions as a space for diagnosis, although they do not perceive its informational value, as they relate them to the context of opinions. These results verify the prevalence of journalism as strongly influenced by conventional offline production routines.
\end{abstract}

Keywords: interactivity; journalism; online participation; collaborative models

\section{Introduction}

In the last few decades, with the spread of information and communications technology, media is going through a process of redefining and adjusting its coverage toward non-linear news models, and it is about encouraging greater engagement [1], faced with the existence of users who have dozens of media organizations at their disposal just a few clicks away. Additionally, these users show attitudes referred to as "collective intelligence" [2]; that is, a position that facilitates building and disseminating knowledge in a participatory and horizontal manner, either partially or fully void of mediation. Faced with these new user attitudes, media is going through a transformation aimed at reverting the loss of credibility [3], which reflects the failure to adapt to the aforementioned collective reconfiguration [4].

Within the transformation of media into the production routines of cyberspace derived from the collective intelligence, the idea of interactivity arises. This is an adaptive factor that favors greater interrelation between media and its users through options related to support [5] or opens more dialog by using collaborative spaces [6].

In this study, we deal with the perception of journalists working in some of the most important cybermedia organizations in three Latin American countries: Colombia, Peru, and Ecuador. These countries have been identified because of their technological gap; that is, the existence of large population groups that are fully or partially disconnected to online media: in 2017, only six of 
ten Colombians [7], five of ten Peruvians [8], and five of ten Ecuadorians [9] had access to Internet. However, Pierre Lévy [2] notices the multilinearity of modern public space: the technological gaps in these countries coexist with the growing importance conferred on online media. For example, in Colombia, the strategic use of technology by young people who protested against Law 30, aiming for greater privatization of education, is emphasized [10]. Another example is the technological appropriation of farmers in the National Agricultural Strike of 2013 [11]. In Peru, a transfer of social movements from the streets to digital platforms has been noticeable [12]. In Ecuador, the electoral victory of the first presidential campaign of Rafael Correa in 2006 tends to be associated with effective management of social networks [13]. In other words, intermediate access to the Internet is not equal to a low impact of technology in the public sphere in these countries, as it was shown, for example, in the Cuban case [14]. On the contrary, online media gains special importance owing to their influence on conventional media and their importance as instruments of civic mobilization.

Through in-depth interviews with journalists in Colombia, Peru, and Ecuador, in this paper, we interpret their professional perspective to learn their understanding of users' contributions to cybermedia news and, in general, their interactive practices. Additionally, we seek to analyze possible changes in the agenda of news organizations, along with the level of contribution among journalists and users, both of which are crucial for news innovation of digital media in these countries. The results can be interesting because they will present an analysis of journalistic routines in three countries where this phenomenon has not been deeply studied, but also in order to describe practices which can be similarly recognizable in different contexts.

In the next pages, we discuss the theoretical framework, based both in the definition of interactivity in cybermedia, and the concept of passive and active users and its relation with online participation.

\section{Theoretical Framework}

\subsection{Toward the Definition of Interactivity in Cybermedia}

It is complicated to establish a single idea to describe interactivity [1] because of the continuous development of this notion, which is associated with constant improvements that are suggested and expanded by technical options. In the following sections, we define the "interactivity" beginning with the fact that numerous authors emphasize interactivity as one of the distinctive factors of online media [1,5,6,15-24].

Williams et al. [25] described interactivity as a process of exchanging roles, wherein on the first level, content localization devices such as a digital newspapers and periodical libraries are combined, while on the second level, the possibilities to alter the message by its receivers are reduced.

Pérez-Luque (1998)—as explained by Martínez [26] (p. 276)—considered interactivity in relation to content selection by users and identified two fundamental dimensions within its conceptualization: the first based on the level of interaction of users with sources, writers, advertisers, or other users and the second based on the level of interaction with the news message; that is, with the news organization's agenda and topics or elements that shape them topics.

For his part, the author of [26] classified the types of interactivity in digital media as per the level of user participation. Accordingly, there is, in particular, reading or navigation interactivity; limited answer interactivity; conditioned creative interactivity; and open creative interactivity. Reading or navigation interactivity is limited to the selection of news content by the users. In contrast, limited answer interactivity offers the possibility to choose between a series of pre-established answers, as in the case of binary response surveys: yes or no, and agree or disagree. Creative interactivity facilitates editing and the creation of original content, but user participation is limited owing to guidelines imposed by cybermedia organizations in relation to the information topics and possible editing. Finally, the author describes open creative interactivity, which establishes a more developed space for participation, where users create creative content without restrictions in terms of development or content editing. 
However, this definition has been nuanced by some authors [27], who state that interactivity performed by means of a machine or a device produces a simulation. This is because interactivity, in fact, is achieved only when the receiver-user directly intervenes in developing content; that is, when the user is able to communicate with the sender and to intervene in the creation and dissemination of content. In fact, thanks to the interactive options offered by technological devices, the possibilities of users to participate have increased exponentially. In some cases, participation on a digital platform may even cause a direct intervention, in real time, with regard to the content found on websites, where its modification is possible because of the interaction options offered by cybermedia organizations.

Likewise, in spite of all the classifications for degrees of interactivity offered by Arrojo [27], all of them agree that through this process, multidirectional communication is generated to a great extent, which Rost [28] summarizes in the relationship between users and the medium, users among each other, and users and content writers.

Interactivity is difficult to describe owing to some of its attributes, such as its interdisciplinary nature, given that the term is studied from the perspectives of different disciplines such as computer engineering, communication studies, or library sciences. However, there have been some notable attempts to assess the quality of the interaction managed by cybermedia. In this sense, the set of 36 indicators grouped according to six parameters stand out, as suggested by [5]. These parameters comprise the assessment of interaction of a user with other users, a user with a cybermedia organization or the author of the news, or the presence of the website on social media, among others.

\subsection{Passive Audiences and Active and Participative Users}

The first communication cybermedia, as explained by [29], dates back to the mid-1990s. However, these pioneer organizations on the Internet turned out to be copies of the printed editions. Later on, with the cost reductions of computer equipment and the constant increase of digital consumption by users, websites began to assume that, instead of reproducing the trends of conventional news language, news organizations should reinvent themselves to adapt to the new format. Thus, according to [20], the consolidation process of cybermedia began in 2006, with the development of numerous interaction options. Essentially, this situation was the result of users' participatory aspirations [22] and, with the media trying to be in the limelight again, monopolizing the management of public opinion. Based on these participatory mechanisms, cybermedia is rethinking how to stimulate greater interaction with its users, what design and narrative strategies may be useful [1], and how to establish greater loyalty [24] in a highly fragmented and competitive global market, owing to the emergence of numerous native digital media [29]. According to [15], upon facing these challenges, news organizations had to face a profound change both in the traditionally accepted relationship with their audiences and in the way of conceiving journalism. This challenge, as stated by this author a decade ago-yet holding a valid reflection even today-is in constant evolution, in the search for solutions that help alleviate the loss of credibility and audiences that have been damaging media since the 1980s [30]. Thus, interactivity emerges as an important factor when it comes to innovation, which erodes the traditional impenetrability of several media organizations, as well as its association with political or economic powers and later scandals and loss of prestige: "Journalism's openness cannot be avoided to revitalize the organizational structures that in some cases are on the verge of disappearance; prestige was mentioned but it is important to note that severe economic causes, above all, led to the credibility crisis" [3] (p. 117).

Through the convergence of online communication, media have tried to stop the decreasing numbers of users [17], many of whom keep themselves informed only through native digital or social media. This convergence also aims to stop the loss of advertisers and social importance once the moderating role of conventional news platforms fades. Evidently, this progressive process cannot be understood without placing it into the context of the loss of credibility mentioned above [3], which has worsened because of the gradual transformation of users, thanks to the ease offered by new media. Thus, consumers are no longer passive receivers-those who receive information in one way-but 
active users who aim to participate in the creation and dissemination of content [27,31]. In this sense, a new form of understanding journalism has strongly emerged, suggesting that journalists should transfer the control of information to become professional managers of participation [32]. Therefore, interaction is the main characteristic to be exploited, either in specific sections under the label of civic journalism or similar ideas, or as a structural principle to apply to the content disseminated by the online media organization.

In spite of the various ways of interacting suggested by cybermedia, not all users show the same interest regarding participation in coverage, as many of the reception routines related to conventional media prevail [23]. Thus, it can be said that all users who access information through new media stand out because of selective interaction, which, according to [28], refers to the selection of content by audiences. However, only a few users show maturity in relation to communicative interaction, which describes the creation of content by users [28]. Accordingly, two types of users can be identified: passive users, whose consumption practices appear to be related to those of offline media audiences, and active users, who are also called producer-consumer users [32] or producer users [19,26]. In spite of the existence of these conceptual labels, the fact is that active users seek to intensify, in a multidirectional way, their interaction with media. This process begins with the selection of the cybermedia news; searching for, selecting, and reading content of interest; or direct participation on the website by the means of comments, voting, suggesting journalistic content, sending images, evaluations, or requests for corrections or clarifications, etc.

Moreover, also known as prosumers — consumers and producers—-these active users are engaged in the editing, development, distribution, creation, and co-creation of content and are defined as sources of information for media, as they can facilitate useful material for the creation of news pieces.

There are different degrees of participation agreed on by users within this category; for example, those who expect to contribute with text or audiovisual resources and those who maintain a social or community-oriented informative experience: "The participation of users as Internet content 'creators' covers multiple realities that may be limited to a strictly interpersonal environment or have a vocation of 'public production' aimed at sharing ideas, opinions, information, and knowledge among other possible Internet users, thanks to options created by the new media environment, which allows communication in several ways" [26] (p. 270).

In this context, young users appear as active participants with a "tendency toward prosumer hyperconnection" [33] (p. 41), as for young people, websites are spaces to exchange, since they access the Internet and digital media, preferably, as news platforms [34]. Moreover, the authors of [35] and [18] mention that young users make the most of interactivity, as they are born under the idea of digital culture; therefore, this group uses the Internet to satisfy part of their emotional and experience-based needs. In contrast, social networks, which play a major role in news consumption for young people, are spaces for active participation by these users.

However, when it comes to the levels of interaction perceived by users within cybermedia, there are studies stating that the need for cognition and online management of users should be considered, as stated by Tremayne (cited in [21]). On the basis of this fact, the author of [21] conducted a study on how perceptions of online interactivity affect preferences in the consumption of digital media in relation to offline media and concluded that interactivity positively influences the quality of information processing. In another study, after interviewing university students in Colombia, Peru, Chile, and Spain, the author of [23] concluded that passive profiles were three times more frequent than the active ones. Thus, it was more important to activate mechanisms of selective interaction to the detriment of the mechanisms of communicative interaction, which demand greater development of a digital culture in basic learning environments, such as educational institutions.

\section{Objectives}

This study has the following general objective: 
To evaluate the concept of interactivity used by journalists who work in some of the most important news organizations in Colombia, Peru, and Ecuador.

Likewise, we propose the following specific objectives:

1. To identify the importance of user participation conferred by these professionals in the organizations where they work.

2. To determine to what extent user interaction can cause changes in the news agenda of cybermedia where the interviewed professionals work.

\section{Methodology}

\subsection{Design and Researching Technique}

Studies that seek to analyze interactivity tend to focus on the involvement of users in media organizations [1]. In this non-experimental study with a descriptive approach, we focus on delving into the interaction between journalists and users, for which we talked to journalists working in national media organizations in Colombia, Peru, and Ecuador.

To that end, we conducted in-depth interviews, which are relevant qualitative techniques facilitating the comprehension of unobservable phenomena directly [36]. In concrete, we have followed the second model of in-depth interviews mentioned by the quoted authors, whose aim is to learn about the activities which cannot be observed directly.

\subsection{Validation and Pretest}

Because this is an international and comparative project and to consolidate an equivalent discourse in each country, the model of in-depth interviews explained by [37] was followed. In other words, this was carried out through a structured instrument, a recommended procedure when there is a numerous group of individuals interviewed [36]. The instrument included a section to establish the context of the interviews, called "General Information"; a section containing general questions to characterize the subject or interviewee; and a total of 22 questions or variables, which were built based on the findings or conclusions presented by the authors consulted $[5,6,16,38-43]$.

In January 2018, and as it is recommended in qualitative methodology [36], validation of the quality of this first draft was carried out through two strategies, experts' validation and a pretest with a small sample of interviews. First of all, we invited several researchers of online media in Ibero-America to review the proposed instrument, in order to improve its quality with their points of view. We selected the experts according to one essential rule: all of them had, at least, one academic publication about interactivity in online media. After they agreed to participate in this study, we sent them attached the instrument by email, and they were asked about the clarity and relevance of statements. Altogether, the following professors agreed to be part of this expert panel: Carlos Arcila Calderón (University of Salamanca, Spain); Moisés Limia (Universidad do Minho, Portugal); Abel Suing (Private Technical University of Loja, Ecuador); Elba Díaz Cerveró (Panamerican University, Mexico); Leticia Castillo Quiñónez (Autonomous University of Ciudad Juarez, Mexico); Amaro La Rosa Pinedo (University of San Martín de Porres, Peru); and Sandra Lucía Ruiz (Panamerican University, Colombia). The suggestions provided by these experts were useful to improve the outline, to replace some variables, or to create other variables.

After the experts' participation, secondly, before applying this instrument, we conducted a pretest [36] via three interviews conducted with subjects who possessed the characteristics demanded by the sample.

\subsection{Sample and Sampling Method}

A non-probabilistic convenience sampling was used, given that the interest of the study is not to generalize the results, but to understand deeply journalists' concept of interactivity in these three countries. In that sense, we contacted 45 journalists ( 15 per country), who voluntarily decided or 
declined participating in the study. As suggested in other studies [6], we only contacted journalists who, at the time of the interview, were working at top media organizations in their respective countries (Table 1).

Table 1. Alignment of specific objectives, population, and sample design.

\begin{tabular}{|l|l|l|l|l|}
\hline $\begin{array}{l}\text { Specific } \\
\text { Objectives }\end{array}$ & Population & Technique & Sample \\
\hline $\begin{array}{l}\text { To identify the } \\
\text { importance of user } \\
\text { participation } \\
\text { conferred by these } \\
\text { professionals in the } \\
\text { organizations } \\
\text { where they work. }\end{array}$ & $\begin{array}{l}\text { Journalists working } \\
\text { at national media } \\
\text { organizations in } \\
\text { Colombia, Peru, } \\
\text { and Ecuador. }\end{array}$ & $\begin{array}{l}\text { Non-probabilistic } \\
\text { convenience } \\
\text { sampling }\end{array}$ & $\begin{array}{l}\text { In-depth } \\
\text { interviews }\end{array}$ & $\begin{array}{l}\text { The numbers of } \\
\text { journalists who } \\
\text { agreed to } \\
\text { participate in the } \\
\text { study are as } \\
\text { follows: } \\
-13 \text { in Colombia } \\
-10 \text { in Peru } \\
12 \text { in Ecuador }\end{array}$ \\
\hline $\begin{array}{l}\text { To determine to } \\
\text { what extent user } \\
\text { interaction can } \\
\text { cause changes in } \\
\text { the news agenda of } \\
\text { cybermedia where } \\
\text { the interviewed } \\
\text { professionals work. }\end{array}$ & $\begin{array}{l}\text { Journalists working } \\
\text { at national media } \\
\text { organizations in } \\
\text { Colombia, Peru, } \\
\text { and Ecuador. }\end{array}$ & $\begin{array}{l}\text { Non-probabilistic } \\
\text { convenience } \\
\text { sampling }\end{array}$ & $\begin{array}{l}\text { In-depth } \\
\text { interviews }\end{array}$ & $\begin{array}{l}\text { The numbers of } \\
\text { journalists who } \\
\text { agreed to } \\
\text { participate in the } \\
\text { study are as } \\
\text { follows: }\end{array}$ \\
\hline
\end{tabular}

Source: Created by the authors

Finally, 35 journalists accepted to participate in the study. All the interviews were conducted between February and September of 2018 in the three countries by phone. The 35 journalists consulted were working at the following media organizations (some of them were working at the same organization) (Table 2):

Table 2. Media organizations where the consulted journalists work.

\begin{tabular}{|c|c|c|}
\hline Colombia & Peru & Ecuador \\
\hline El Tiempo & IDL Reporteros & El Comercio \\
El Espectador & Libertad Digital & La Hora \\
Caracol TV & Radio Nacional & 4 Pelagatos \\
Canal Capital & El Comercio & Ecuador Inmediato \\
La Silla Vacía & Perú 21 & Teleamazonas \\
Las 2 Orillas & Latina TV & Ecuador TV \\
Rutas del Conflicto & Revista Poder & El Telégrafo \\
& iForex Financial News & Radio Quito \\
& & Radio Casa de la Cultura \\
& & Agencia de Noticias Andes \\
& & Diario Opinión de Machala \\
& & Radio CRE Satelital \\
\hline
\end{tabular}

Source: Created by the authors

\subsection{Instrument and Analysis Procedure}

To maintain confidentiality over the identity of the journalists interviewed, the opinions stated in the results section have been anonymized according to the order in which they were consulted and according to each country: Colombia (C), Peru (P), and Ecuador (E). Given that diverse sample, the analysis was carried out organizing a matrix of variables and indicators. First of all, in this matrix, all the transcribed answers of the three countries were placed together question by question. The answers were anonymized as it was explained previously. Secondly, as is described by [44], 
some authors recommend to use different analysis techniques with the same data or researching problem until the hidden meanings are revealed. In our case, to recognize the patterns or categories [36] in such a diverse sample, we started the analysis identifying the indicators question by question. Then, we continued with a coding process [44]: all the indicators related were grouped in distinct codes. Moreover, the codes were compared until the concepts and the categories emerged, which concentrated a significant part of the interpretation. Finally, and after it was organized-a general scheme in categories, concepts, codes and incidents - we continued writing the results treating to consolidate a deep interpretation of the data generated by the answers.

\section{Results}

\subsection{User Value and Contributions to Cybermedia News}

After interviewing journalists in Colombia, Peru, and Ecuador regarding the importance of user contributions to online media, we confirmed that most of them deem it important that users value or rate the published content, primarily because it is a way to get feedback and constant criticism that allows them to improve their work: "It's like a thermometer, if we publish quality information, we would like to know how the audience responds to it" (C13), mentioned one of the journalists. Additionally, they consider these participation enclaves to be beneficial for the media organization, as these are spaces for diagnosis that show the audience's point of view regarding the topics or approaches taken on these topics. In this line of inquiry, we found two answers-both from Peruvian journalists-that hesitated regarding the effectiveness of these assessments provided by users: "I don't think it's useful because it is a never-ending conversation and may reach a level that is somewhat violent or controversial" (P2). In any case, the analysis of this contribution is conducted by a professional team, which is in charge of dealing with requests from audiences and generating feedback for writers or executives, or most commonly, in a non-structured way; that is, through inquiries made by each journalist on professional or personal social networks, or even through WhatsApp groups, to encourage civic engagement.

However, an important mechanism for community interaction, such as comments from users, receives diverse receptions. Most of the interviewed journalists tend to read these comments, aiming to know the opinion of the readers regarding the published content. Likewise, the consulted professionals find it important to receive feedback and take reviews into account for future work. In addition, they believe that comments are useful to check which topics are interesting for the users: "Yes [I read them] to get feedback, to take into account constructive reviews, and to know where I am failing" (C11). However, in general, the aim of journalists when reading comments is not to start a conversation or to provide a response to the users' comments, provided that, when it comes to these enclaves, their opinions are different; many of the interviewed journalists acknowledge its importance but report rude behavior from some users: "Most of the comments are useful because many of them come from professionals and provide another approach to what we write and also because they correct writing or typographical mistakes, but not all of them because others are posted to criticize or offend" (C3). In other words, some of the comments made by readers are perceived as useful, as they widen the discussion fostered by the news content: "Yes, they contribute to the content. It's interesting. When I published an article about Korea, someone published a table on imports and exports explaining how exports from China have dropped. I was very grateful for the contribution" (P8). On the contrary, at times, journalists believe that comments are offensive because users misunderstand the approach of the content, simplify the news event or attack by using more personal, emotional arguments rather than reasonable ones: "On social networks, when you read a comment, they show the user's ignorance on the subject. For example, they do not read the article; they get carried away by the headline, or maybe by the knowledge they already have regarding the topic; they criticize your articles without even reading them and, as the topics are controversial, they write all kinds of things" (E4). 
A variable to take into account with regard to user comments is the kind of media organization where the professionals work, as some of them may influence the conversation held by journalists and their audiences. Particularly, within the type of a media organization, we focus on aspects such as support, the tradition of standardized participation in the editorial environment, the existence of a professional team in charge of managing participation, and the organizational strategies authorized to encourage interaction. Thus, some of the interviewees-especially in media such as radio-acknowledge that their news organization fails to take advantage of comments made by users, as communication mechanisms such as phone calls are preferred.

According to the journalists consulted from these three countries, the contribution made by users has an essentially prospective value; that is, it is used only for diagnostic purposes. However, civic contributions are not related to news value; most of the professionals believe that few users are qualified to create content with certain journalistic value. Some of them consider the work of a journalist as a necessary labor within information processing: "I believe in the value of the journalist as curator of user content. Possibly, a user may be able to create quality journalistic content, but it is necessary to include the journalist as part of the process" (P6). On the contrary, another journalist said, "No, because it's one thing to know about a specific topic being dealt with and another to know how to journalistically structure a text in a correct manner, with journalistic rigor, and for this reason, the journalist is trained" (C3). Furthermore, some journalists agree that users are not qualified for such work: "No, they don't go beyond tweets or what social networks say. Most of them don't, because this is very light information" (C9).

Additionally, most of the journalists in these three countries believe that user participation is useful within the realm of opinion; that is, setting aside civic contribution, which is clearly differentiated from the information, as explained by one of the professionals consulted: "Maybe with opinions, it depends on the area. I really value people's opinions, but generally speaking, these are not texts that can be recovered for publication" (E3).

As mentioned before, most of the journalists interviewed believe, on the one hand, that user comments contribute very little to the content published by the media, and, on the other hand, their audiences, in general, are not qualified to contribute to the content with a certain journalistic value. However, most of the professionals consulted believe that these spaces for communicative interaction are beneficial, as they create spaces for participation and debate, as well as greater transparency on the information published: "Yes, journalism has to be public in every field. Feedback must be present, and that feedback has to be public" (C3). Furthermore, another interviewee mentioned, "Yes, I leave them. So far, we haven't had the need to delete any of the comments. If the quality is poor and fails to contribute something, maybe I would agree to delete a comment, but generally I leave them in order to avoid the feeling of censure" (P8).

However, when it comes to publishing content created by users, some of the interviewees agree that such content should not be published because of the fact that the content lacks journalistic rigor, although some of the professionals admitted that they have started research based on information provided by their audience. From this point of view, it is common for that content to become sources: "Usually, we review the content and treat it as a journalistic element that needs to be confirmed, contrasted, and compared with other sources" (P6), as one of the journalists mentioned. Another interviewee stated, "We write reports or they can become a source for reporting" (C13). Additionally, some of the interviewees mentioned that user contributions are published in opinion sections, with spaces to post a comment as well. Finally, many of the professionals agree that this information may alert them about some topic that their audiences wish to deal with: "In the news organization where I work, the content provided is treated as ideas, in the context of dealing with a source that alerts us about some topic. Strictly speaking, we are a news organization of rigorous journalism, and all that should be digested" (C4). 


\subsection{Changes in the News Agenda and Failure to Collaborate with Users}

This is an example of an equation: According to the journalists interviewed in Colombia, Peru, and Ecuador, mobilization of users through online platforms may cause changes in the news agenda of media organizations. This is explained by the attention that the media places on the conversations held on social networks. Based on aspects such as the number of likes or the number of times the content has been shared or retweeted, a topic may be included in the latest news coverage: "Of course, public opinion determines a news organization's agenda. If everyone is talking about a topic at the national level, it is possible that a news organization breaks news about that" (E11). However, this process passes through a filter stage based on corroboration and verification.

Peruvian journalists were found to have the most answers related to the failure to pay attention to trends in social networks, in a way that, in this country, is not likely for a topic that has an impact online to have relevance in the media's agenda: "I think it is not strong enough yet, at least in the news organization where I work, because journalists also hold themselves to their judgment. Sometimes, what people say is not taken into account, not as much as the situation. This is due to lack of staff and failure to refocus the production of the show" (P3). For those who believe that user topics have an impact on the topics in the media-most of the journalists in the three countries-together with relevance indicators, such as the aforementioned likes or times that content is retweeted, another aspect to take into account is the time for which the content remains a trending topic on social networks: "Yes, I do believe when there is an impact and an insistence on social network, it can have an impact and can generate an agenda in the environment" (C11). According to our interpretation, the inclusion of these topics proposed by people is caused by both social responsibility, which is a characteristic of the media; the need to verify or reject the signs created through social networks and the importance given to online audience, which causes traffic on news websites-consequently, investing in digital publicity—although, at the same time, it helps promote the concerned media organization.

Similar to comments, journalists possess an ambiguous concept with regard to user participation. On the one hand, the possibility of users correcting news published by cybermedia is perceived as an insult against the professional values of journalism. On the other hand, the consulted professionals agree - in Colombia and Ecuador but not in Peru—that users should be able to select headline topics based on individual interests. Regarding the first, most of the interviewees believe that users should not be able to correct news in real time, as they believe the work of journalists is essential for information processing. In this sense, allowing corrections in real time may bias the information: "No, the work of the journalist is to provide verified information. The journalist is trained for that, the user is not. I don't agree with modifying the news as is the case with Wikipedia. Besides, Wikipedia has proven to be a non-functional model" (P2). "It is a complex issue. I believe the work of journalists is discredited, there is a lot of work done behind the story. During the investigation, citizens must take into account, otherwise, this truthful research would be discredited or it would lose prestige" (C11), mentioned two of the interviewees. Only four of the consulted professionals positively reacted to the idea of users pointing out possible errors in the information created by journalists: "It would be great because many mistakes are made due to immediacy in real time, and it would be wonderful to have at our disposal that constructive information to correct the mistakes immediately" (C2). In addition, it would be very important to create a verification system in case the media decides to enable this possibility: "It would be ideal, but we would need tools that allow editorial control since digital vandalism may be generated" (P7).

However, as previously stated, most of the journalists interviewed in Colombia and Ecuador agree that users should be able to customize the topics of cybermedia headlines based on their preferences, as they find it important for audiences to choose the order of the information according to their needs and tastes. In spite of this, the consulted journalists also alert about the bias that may be present upon developing communities that fail to communicate with each other: "[ ... ] this causes risks, as contact should be established regarding topics that are not considered important. This could cause social 'bubble' effects. Risk is present. Contact should be established regarding topics that are not interesting; 
that is, there needs to be some sort of balance, I would say" (C5). Furthermore, the front page is considered an important aspect of the identity of some general media, in a way that the development of specific media-with the selection of topics of interest for the users-could blur the scope of the media: " $[\ldots]$ the front page is general. We report on situations and research topics ... If a person wants to read only about certain topics, there are other spaces such as specialized magazines" (E3). However, while journalists in Colombia and Ecuador are in favor of this initiative, journalists in Peru have opposite opinions. Generally, they believe that users should not be able to customize the topics on the front page because, as they stated, relevant topics for users can be omitted. One of them even mentioned, "No, it is similar to what happens with prosumers: people can produce any amount of information, but the ability to select it and the journalistic judgment are part of professional training" (P4). Another journalist responded the following: "It's a possibility, although it would entail a problem beyond the technical ones: that users lose the possibility of seeing relevant content. Partial access to that content may be a solution" (P7).

\section{Conclusions}

The concept of interactivity of journalists from Colombia, Peru, and Ecuador has not been a topic deeply investigated. In that sense, the findings presented advance the current knowledge in this topic, by proposing a controversial concept of interactivity. On the one hand, the consulted professionals positively value the possibility of knowing users' responses to the content that they publish. They also frequently resort to comments as diagnostic spaces that help to reveal the audience's perceptions. Likewise, journalists frequently visit social networks to assess the mood of public opinion, to look for signs that may become research, or to analyze which topics are currently trending. On the other hand, the interviewed journalists tend not to respond to comments from users and think that their audiences are not qualified enough to be involved in the creation of content having journalistic value. Consequently, civic contribution is not related as part of a horizontal perspective on the construction of information [2] in that users are actively involved in the development of topics. Rather, after conducting the interviews, we perceived that journalists take advantage of the ease provided by these new spaces to expand or revitalize some options already present within conventional production routines, such as receiving testimonies or ratings, or to detect trends.

In sum, on the basis of the interviews, the contributions of audiences are set aside preferentially for an asynchronous prospective use; that is, to spaces where there is no direct contact. Therefore, there is no probable or expected response from journalists. When this contribution causes a more organized reflection, this is placed in specific section of the media website, or more frequently within the opinion section, as a way to contrast the specialized opinion of the media while introducing the social point of view.

Thus, we found that the way consulted journalists manage online participation is similar to practices related to offline routines (Figure 1), something that we also stated in another study when analyzing the interaction mechanisms of the 87 top national cybermedia organizations in Colombia, Mexico, and Ecuador [6]. One of the aspects of greatest influence on this concept is the type of media, according to support, strategies, or available equipment to manage these interactions. Thus, the media organizations to which the interviewees belong still do not facilitate, for the most part, a systematization approach to user opinions, in a way that only a minority of the interviewees recognize the existence of specialized teams for this task in their editorial offices.

Paradoxically, aspects such as collective intelligence suggest that a change is needed in the process of information creation, development, and dissemination, as recommended by [31]. In this transformation of journalism, the user becomes the center from where the news is created, by being involved in the broadcasting and reception and by actively monitoring errors or omissions made by professionals. 


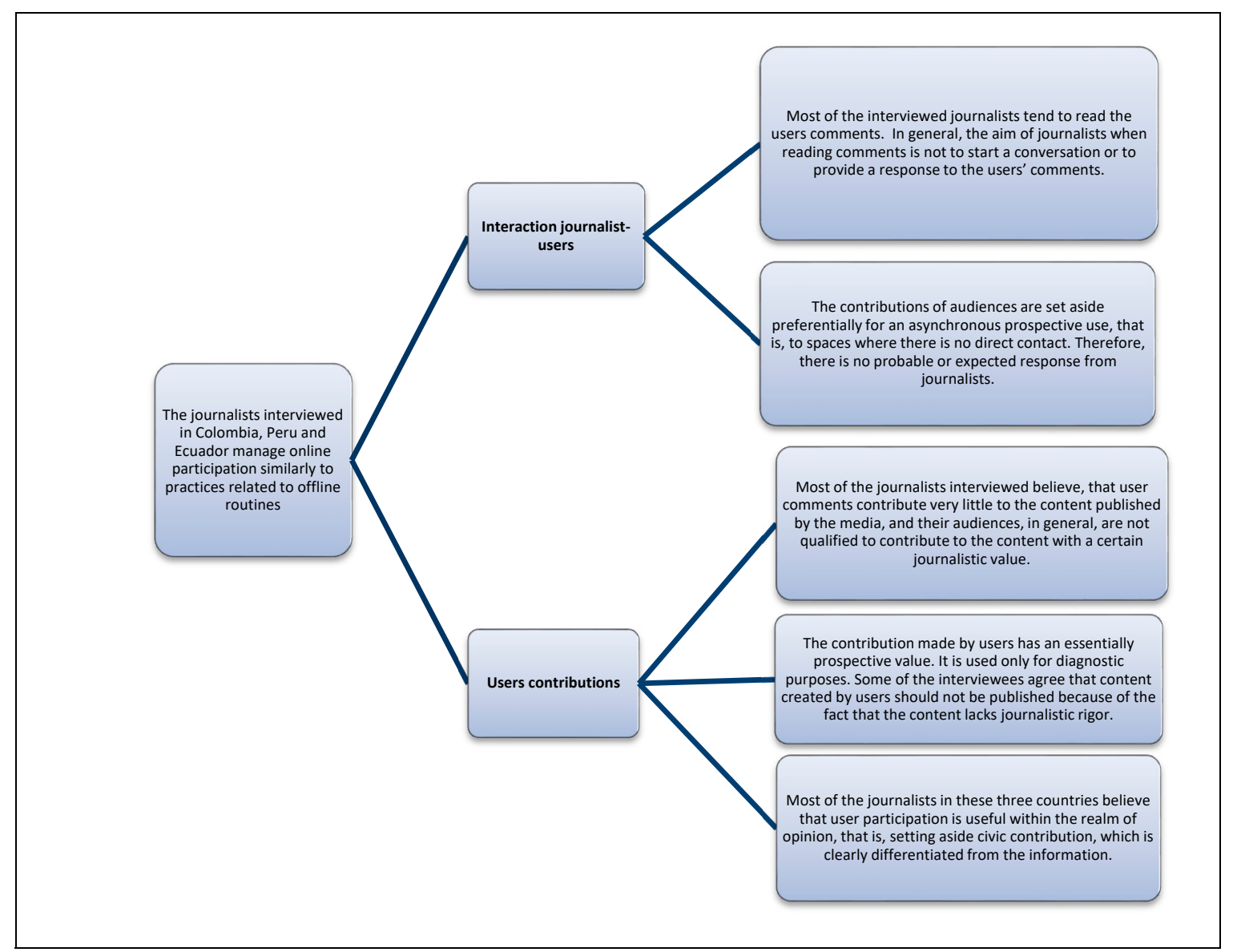

Figure 1. Interactive practices of the journalists interviewed in Colombia, Peru and Ecuador. (Source: Created by the authors)

The functioning of some collaborative models of knowledge construction is correctly identified by the consulted journalists. But their opinions regarding this matter tend to be negative. There is a reason why some of them provide opposing references to Wikipedia, the collaborative encyclopedia par excellence-they believe that correction in real time may bias the information, as it is complicated to monitor. Additionally, most of them claim that user contributions should be focused on opinions-comments, ratings, letters to the editor, columns, and participation on blogs-rather than in the creation of content with news value.

It is possible that these negative views are related to the type of user that the consulted journalists refer to. In other words, with audiences that show a preference over selective interaction [23] and a closer connection with consumption-instead of message production-it is possible to identify a lack of social interest involved in greater collaboration. In addition to the residual problems of the conventional public sphere of these countries, such as intolerance, elements that are typical of receivers identified by the technological gap are added; for instance, problems related to digital illiteracy and, in general, societies still believing that messages disseminated by offline media are more reliable.

Nevertheless, user participation can modify the agenda of a media organization, given that journalists are not disconnected from the conversation being held by people on social networks. Precisely, those enclaves are useful for the consulted journalists, as they help increase traffic on the website and grant social legitimacy to the content disseminated by media organizations. Moreover, these information providers are highly exploited by the interviewed professionals, who tend to receive complaints, suggestions, and creativity-in short, civic conversation-to build products from the perspective of what is technically appropriate in journalism. 
In conclusion, we noticed tension between professional values conceived over decades of journalistic work and some new ideas regarding appropriation of user information. And, from that point of view, journalism should adapt its routines in order to incorporate the technology [4] in its narratives. In this sense, cybermedia innovation may be important, in particular, for a greater development of its structural options on interaction, such as customized designs of covers; strategies to have a dialog with the people, such as allowing more responses to comments on the website or social networks; creating products related to user impulses, such as tweet-interviews or group cyber interviews; and the integration of these in the narratives, for instance, by mentioning the sources taken from the Internet. Therefore, we find training, incentive, and regulation of the interactivity suggested by online cybermedia to be fundamental.

Finally, it is important to mention the limitations of the results presented above. First, these results cannot be generalized because of the study's qualitative approach. Furthermore, as Internet access is developed - and the technological gap is reduced-interaction between journalists and users might be modified or intensified. However, from our point of view, it is interesting to continue with research on the relationship between technology and journalism in Latin America, specifically because many of the concepts provided by prior literature fail to contribute in relation to the explanation of the elements that distinguish the journalistic culture from other contexts. With this study, we attempt to contribute to this debate, within the fascinating phenomenon of online participation through media.

Author Contributions: Conceptualization, D.B. and K.P.; methodology, D.B.; investigation, D.B., K.P., U.F.T. and N.M.M.; formal analysis, D.B. and K.P.; writing—original draft preparation, D.B. and K.P.; writing-review and editing, D.B., K.P., U.F.T. and N.M.M.; project administration, D.B.; funding acquisition, D.B. and U.F.T.

Funding: This research was funded by Universidad del Rosario (Colombia), grant number [IV-FGI001].

Conflicts of Interest: The authors declare no conflict of interest.

\section{References}

1. Ksiazek, T.B.; Peer, L.; Lessard, K. User engagement with online news: Conceptualizing interactivity and exploring the relationship between online news videos and user comments. New Media Soc. 2016, 2, 502-520. [CrossRef]

2. Lévy, P. Inteligencia Colectiva. Por una Antropología del Ciberespacio; Organización Panamericana de la Salud: Washington, DC, USA, 2004.

3. Barredo, D. La crisis de credibilidad de las organizaciones periodísticas: Hacia la sociedad de los ideantes. Poliantea 2013, 2, 101-126. [CrossRef]

4. Rubira, R.; Gelado, R.; Magro, S. La profesión periodística frente a los retos de internet. In Periodismo Digital: Tras las Comunidades Sostenibles en el Ciberespacio; Larrea, A.M., Mantilla, P., Eds.; Egregius: Sevilla, Spain, 2018; pp. 81-97.

5. Rodríguez, R.; Codina, L.; Pedraza, R. Indicadores para la evaluación de la calidad en cibermedios: Análisis de la interacción y de la adopción de la Web 2.0. Revista Española de Documentación Científica 2012, 2, 61-93. [CrossRef]

6. Barredo, D.; Díaz-Ceveró, E. La interactividad en el periodismo digital latinoamericano. Un análisis de los principales cibermedios de Colombia, México y Ecuador (2016). Revista Latina de Comunicación Social 2017, 72, 273-294.

7. MINTIC. Boletín Trimestral de las TIC. Cifras Segundo Trimestre de 2017. Available online: https: //colombiatic.mintic.gov.co/679/articles-61583_archivo_pdf.pdf (accessed on 11 November 2018).

8. GFK. Informe de Internet 2017-Digital Marketing Toolkit Peru. 2017. Available online: https://www. gfk.com/es-pe/insights/press-release/informe-de-internet-digital-marketing-toolkit-peru (accessed on 14 March 2019).

9. El Universo. Internet fijo llega al 36\% de los hogares en Ecuador. Available online: https://www.eluniverso. com/noticias/2017/07/02/nota/6258349/Internet-fijo-llega-36-hogares (accessed on 11 November 2018).

10. Parra, E.; Pinzón, N. Entre la Representación y la Movilización: Escenarios de Participación en Colombia (1991-2014). Reflexión Política 2015, 2, 60-73. 
11. Aguilera, J. Redes y movimientos sociales, el caso del paro nacional agrario en Colombia. In Comunicación Digital: Participación y Movimientos Sociales en América Latina; Arcila, C., Barredo, D., Castro, C., Eds.; Sociedad Latina de Comunicación Social: La Laguna, Spain, 2017; pp. 25-56.

12. Ojeda, R. Ciudad, redes y procesos caóticos en el Perú actual. Apuntes de Ciencia E Sociedad 2017, 2, $227-235$.

13. Rivera, J. Rafael Correa y las elecciones 2006. Inicios del Marketing y Comunicación política digital en Ecuador. Chasqui. Revista Latinoamericana de Comunicación 2014, 126, 116-123.

14. Rubira, R.; Gil, G. Political communication in the Cuban blogosphere: A case study of Generation Y. Glob. Media Commun. 2013, 2, 153-178. [CrossRef]

15. Llano, S. Hipermedia e interactividad en el periodismo digital colombiano. Palabra Clave 2005, 12, 113-129.

16. Scolari, C. Hipermediaciones: Elementos Para una Teoría de la Comunicación Digital Interactive; Gedisa: Barcelona, Spain, 2008.

17. Cebrián, M. Comunicación interactiva en los cibermedios. Comunicar 2009, 2, 15-24.

18. Cabrera, M.Á. La interactividad de las audiencias en entornos de convergencia digital. Icono 14 2010, 2, 164-177.

19. Fenoll, V. Usuarios activos y pasivos. La interactividad de la audiencia en los medios digitales. El caso de la Fórmula 1 en Valencia. Aposta-Revista de Ciencias Sociales 2011, 2, 1-26.

20. Rost, A. Periodismo e interactividad: Preguntas, definiciones y desafíos en la participación de los usuarios. In Cartografía del Periodismo Participativo; García de Torres, E., Ed.; Tirant Lo Blanch: Valencia, Spain, 2011; pp. 14-36.

21. Broekhuizen, T.; Hoffmann, A. Interactivity perceptions and online newspaper preference. J. Interactive Adv. 2012, 2, 29-43.

22. Fondevila, J.F. El uso de hipertexto, multimedia e interactividad en periodismo digital: Propuesta metodológica de ranking de calidad. ZER-Revista de Estudios de Comunicación 2014, 2, 55-76.

23. Barredo Ibáñez, D.; De la Garza, D.; Freundt-Thurne, Ú.; Pinto, K.T.; Días, D.L. Cuestionando la existencia del prosumer en Iberoamérica. Un estudio sobre los universitarios de Colombia, Perú, Chile y España. Letral 2018, 20, 183-205.

24. Pinto, K.T.; Barredo, D.; Arcila, C.; Suing, A. La interactividad como un factor clave para la fidelización de las audiencias. Una aproximación al contexto colombiano. In Comunicación Digital, Redes y Procesos en América Latina; Arcila, C., Barredo, D., Castro, C., Hernández, A., De la Garza, D., Eds.; Comunicación Social, Ediciones y Publicaciones: Salamanca, Spain, 2018; pp. 39-48.

25. Williams, F.; Rice, E.; Rogers, E.M. Research Methods and the New Media; The Free Press: New York, NY, USA, 1988.

26. Martínez, L. La participación de los usuarios en los contenidos periodísticos de la Red. In El Ecosistema Digital: Modelos de Comunicación, Nuevos Medios y Público en Internet; López García, J., Ed.; Universitat de València: Valencia, Spain, 2005; pp. 269-332.

27. Arrojo, M.J. Configuración de la Televisión Interactiva: De las Plataformas Digitales a la TDT; Netbiblo: La Coruña, Spain, 2008.

28. Rost, A. Pero, ¿de qué hablamos cuando hablamos de Interactividad? Center Civ. J. 2004, 2, 1-16.

29. Barredo, D. El tabú de la expresividad real. Análisis del tratamiento informativo del rey Juan Carlos I en ABC.es y ELPAÍS.com (2009-2011). Ph.D. Thesis, Universidad de Málaga, Málaga, Spain, 2012.

30. Cassidy, W.P. Online news credibility: An examination of the perceptions of newspaper journalists. J. Comput. Med. Commun. 2007, 2, 478-498. [CrossRef]

31. Bowman, S.; Willis, C. We Media: How Audiences Are Shaping the Future of News and Information; The Media Center at the American Press Institute: Reston, VA, USA, 2003.

32. Bruns, A. The active audience: Transforming journalism from gatekeeping to gatewatching. In Making Online News: The Ethnography of New Media Production; Paterson, C., Domingo, D., Eds.; Peter Lang: New York, NY, USA, 2008; pp. 171-184.

33. Romero, L.; Aguaded, I. Consumo informativo y competencias digitales de estudiantes de periodismo de Colombia, Perú y Venezuela. Convergencia 2016, 2, 35-57.

34. García-Avilés, J.; Arias, F. Pautas de acceso y confianza de los jóvenes hacia los contenidos informativos online. In Breaking the Media Value Chain; Zilles, K., Cuenca, J., Rom, J., Eds.; Universitat Ramon Llull: Barcelona, Spain, 2013; pp. 305-316. 
35. Orozco Gómez, G. Televisión y producción de interacciones comunicativas. Comunicación y Sociedad 2012, 18, 39-54.

36. Taylor, S.J.; Bogdan, R.; DeVault, M. Introduction to Qualitative Research Methods: A Guidebook and Resource, 4th ed.; John Wiley \& Sons: Upper Saddle River, NJ, USA, 2015.

37. Blasco, T.; Otero, G. Técnicas conversacionales para la recogida de datos en investigación cualitativa: La entrevista (I). Nure Investigación 2008, 33, 2-5.

38. Rodríguez, R.; Pedraza, R. Prensa Digital y Web 2.0. Hipertext.net, (7). Available online: https://www.upf. edu/hipertextnet/numero-7/prensa-digital.html (accessed on 18 September 2017).

39. García de Torres, E. Cartografía del Periodismo Participativo; Tirant Lo Blanch: Valencia, Spain, 2011.

40. Casero, A. Más allá de los diarios: El consumo de noticias de los jóvenes en la era digital. Comunicar 2012, 2, 152-158.

41. González, M.S.; Ortells, B.S. La polivalencia periodística de los profesionales en las redes sociales. Estudios sobre el Mensaje Periodístico 2012, 18, 455-463. [CrossRef]

42. Hernández, F.J. E-SQ-MEDIA, Creación e Implementación de una Escala de Medición de la Calidad Percibida en Cibermedios. Ph.D. Thesis, Universitat de Lleida, Lérida, Spain, 2015.

43. Barredo, D.; Palomo, B.; Mantilla, A.; Gard, C. Una encuesta exploratoria para cuantificar la influencia de las redes sociales en las rutinas profesionales de los periodistas ecuatorianos: Reflexiones sobre la mediamorfosis del Ecuador (2014). Anuario Electrónico de Estudios en Comunicación Social "Disertaciones" 2015, 2, 52-80. [CrossRef]

44. Robles, B. La entrevista en profundidad: Una técnica útil dentro del campo antropofísico. Cuicuilco 2011, $52,39-49$.

(C) 2019 by the authors. Licensee MDPI, Basel, Switzerland. This article is an open access article distributed under the terms and conditions of the Creative Commons Attribution (CC BY) license (http://creativecommons.org/licenses/by/4.0/). 